\title{
The dynamics of state ownership: The decisive role of crises
}

\author{
ÉVA VOSZKA*
}

University of Szeged, Faculty of Economics and Business Administration, Kálvária sugárút 1, Szeged, H-6722, Hungary

Received: January 20, 2020 • Revised manuscript received: May 4, 2020 • Accepted: May 31, 2020

() 2021 The Author(s)

\begin{abstract}
The big waves of change in state ownership in the 20th-century Europe moved in the same direction either nationalization or privatization. Yet this homogeneity has fallen apart in the last decade: globally and within several countries, the two directions have changed quickly or even have been appearing in parallel. So, it is worth returning to the question: what is the reason for these reversals? Are there any cycles in the extension and contraction of public ownership? Most studies in this field analyse nationalizations and privatizations separately. They examine closely the aims and motivations, but remarkably few focuses on the causes of changes in direction. Based on the lessons of these latter analyses, this paper attempts to interpret the expansion and contraction of public property within an integrated framework, identifying the emergency situations as key factors of fluctuation. The central role of crises in ownership changes is not fundamentally new in the literature. The novelty of the recent approach is the attempt to unfold the mechanism of their impact, including also the explanation why the previously uniform direction of big waves has been broken up after 2008. We argue that the main reason behind the parallel occurrence of large-scale nationalizations and privatizations in this period is the eclipse of a dominant economic-policy (and theoretical) paradigm, rendering the previously firm background of ownership waves uncertain.
\end{abstract}

\section{KEYWORDS}

nationalization, privatization, state ownership, cycles, crises

\section{JEL CLASSIFICATION INDICES}

B20, H82, L32, P59

*Corresponding author. E-mail: voszka@yahoo.com 


\section{INTRODUCTION}

The expansion and contraction of state ownership in the European countries - alongside occasional sales of state-owned enterprises (SOE) and purchases of private companies took place in large waves. Going back only to the early 20th century, nationalization of firms increased sharply after each of the world wars, during the depression of 1929-1933, and after the oil crises of the 1970s. In the 1980s and 1990s the direction of changes turned to privatization. These repeated waves were described aptly by Davidson - Dyal-Chand (2011: 117), as "moments of state ownership" in which "...seemingly settled questions about the balance of individual autonomy and state authority, the role of the state in regulating property, and the role of property in social ordering rise to the cultural and legal surface". ${ }^{1}$

The large body of research on these "moments" closely analyses their aims and motivations, including ideological, economic and social factors. According to the well-known explanations, nationalization promises development, modernization, compensation for the lack of private capital and crisis management with the bailout of companies and banks, as well as better coordination and planning which are considered to counterbalance the cyclical fluctuations. It promises to voters the decrease in unemployment, increased job security, safety and quality of public services, the improvement in work conditions and the fall in prices due to dismantling of monopolies or extended state subsidies. At the same time, nationalization can benefit private capital by infrastructure development, the increase of aggregate demand, or because the nationalization of other companies may result in the enlargement of the market and state financed orders. Based on all these, politicians expect from nationalization to ensure the proper functioning of the economy, to widen their room for manoeuvring, to keep their positions and attract votes. $^{2}$

Privatization, in turn, as general reasoning states, increases corporate efficiency and competitiveness, re-structures production using private capital, and improves the budget balance with one-off income increments, while decreasing subsidies and ensuring long-term sustainability by stimulating development. Private investors can start new businesses or expand their firms cheaply; limitations of activities are loosened and markets develop with the expansion of the economy. Consumers enjoy falling prices, better quality and wider choice as a result of increased competition, and have a chance to become shareholders. Taxpayers can avoid higher tax due to the income from privatization and the general improvement in economic performance. ${ }^{3}$

\footnotetext{
${ }^{1}$ The authors adapted the term of Bruce Ackerman who used it for constitution-making periods in the United States. The concept has spread beyond the sphere of political science.

${ }^{2}$ The objectives of nationalization are summarized e.g., in Aharoni (1986), Vickers - Wright (1989) and Megginson Netter (2003). Nationalization in peacetime usually goes with compensation (as a purchase or in exchange for state capital injections and subsidies); expropriation without compensation occurred only during the wars and revolutions.

${ }^{3}$ For the objectives of privatization, see for example Yarrow (1986), Vickers - Wright (1989a), Toninelli (2000), Megginson - Netter (2003) and Parker (2003).
} 
Several studies cover both processes, but without emphasis on their connection. They do not address the question of why nationalization prevailed throughout many decades, and in most cases the large wave of privatization is justified simply by criticism of state ownership (and earlier nationalization in the background). ${ }^{4}$ Remarkably few studies focus on the causes of turnarounds in direction or the absence of them.

This paper sets out to explain how the waves arise and their shifts in direction (including the absence of turnaround before the early 1980s). It asks when and why they appear en masse, covering similar measures in several countries at the same time, ${ }^{5}$ what determines their direction and turnaround. It considers the ownership changes after 2008 also as a wave, because they took on a magnitude hitherto unknown: the nationalizations in the United States and Europe in 2009-2012 reached USD 356 billion and USD 390 billion respectively, in each case equivalent to 2.2 per cent of their 2012 GDP, while the scale of global privatization exceeded in absolute terms to the peaks of the 1990s, as well as its proportion to GDP. ${ }^{6}$ We will try to explain the special features of this wave as well.

The analysis is confined to the European countries, but includes also the United States as a system with European roots. A longer-term review of economic history (Voszka 2018) has shown that this country was no exception regarding nationalizations. Several studies claim that the distinctive feature in the U.S. before the First World War was not the scale of state ownership, but its level - the larger role of the federal state and local (city) ownership (Galambos 2000; Glaeser 2001). The United States then tended towards stronger regulation rather than transforming its ownership structure (Galambos 2000; Yergin - Stanislaw 2002; Toninelli 2008). While the degree of public ownership throughout the 20th century was lower than in Europe, it was not inconsiderable, with broad public services offered directly by local governments ${ }^{7}-$ their $^{2}$ outsourcing is the prime meaning of the word "privatization" in the U.S.

The first part of the paper looks at the small stream of literature that goes beyond mentioning the turnarounds and considers whether there are cycles in the spread of state ownership, and if so, what drives them. The second part sums up the strengths and the weak points of these analyses. Based on their lessons, the third part offers a frame to a comprehensive explanation.

\section{EXPLAINING THE FLUCTUATIONS}

The explanations of the turnarounds in ownership changes can be divided into three main groups: social preferences, politico-institutional motives and purely economic factors.

\footnotetext{
${ }^{4}$ Examples of exceptions are Yarrow - Jasinski (1996) and Toninelli (2000, 2008), who add the changed assessment of the state's role; Vickers - Wright (1989) who look also at new technologies and mounting internationalization, and Millward (2011) underlining technological changes, the changing priorities in geo-political strategies and the modified array of policy instruments.

${ }^{5}$ Of course, the waves do not imply homogeneity of countries concerning the spread, methods and consequences of ownership changes, but the explanation of differences is a subject for another analysis.

${ }^{6}$ According to Megginson (2013). For details, see also Megginson (2017) and Voszka (2017).

${ }^{7}$ See also e.g., Glaeser (2001).
} 


\subsection{Social preferences}

Some theories, providing a general framework for investigating ownership changes, rest on fluctuations in general social attitudes. "Are societies predisposed toward oscillations between periods of intense preoccupation with public issues and of almost total concentration on individual improvement and private welfare goals?" (Hirschman 1982: 3). The author's answer is affirmative for psychological reasons, individual experiences and choices: whereas neither collectivist nor individualistic solutions are perfect, the driving force behind the shifts is a disappointment.

A similar oscillation is described by Karl Polanyi (1946/2001), with the notable difference of attributing the shifts to social choices instead of the individual ones. The central notion in his well-known term "double movement" is the self-protection of society from the negative consequences of the free market, for "the market expanded continuously but this movement was met by a countermovement checking the expansion in definite directions. Vital though such a countermovement was for the protection of society, in the last analysis it was incompatible with the self-regulation of the market, and thus with the market system itself" (p. 136). As these developments endanger the advantages of a free market and so of the society itself, the pendulum swings back. This well elaborated theory is proved particularly influential with institutionalists and political economy schools. Coming closer to our subject, some researchers argue there are cycles even in the expansion of state property. We found such empirical analyses on the emerging economies.

Having gained their independence, most of the countries of Latin America and South-East Asia introduced market mechanisms. Later, nationalization spread, followed by privatization again - of which Chua (1995) provides abundant examples: "Two overarching forces seem to drive this phenomenon: markets and ethnicity... these two powerful forces may be in deep tension with one another. In fact, contrary to received wisdom, market solutions in developing countries appear actually to aggravate ethnic hatreds, which in turn subvert market solutions" (p. 303). According to this analysis, a narrow economic perspective is insufficient for explaining the shifts; it is worth integrating it with the political and cultural factors. In a market system, inequality grows, notably by giving privileged positions to the external, "imperial" forces or "foreigners within" - the latter being specific ethnic groups, in Asia mainly Chinese, in Latin America an "aristocratic elite" which cooperates with the external groups. Opposition parties strengthen and utilize nationalist feelings against these groups, and having come to power, nationalize companies. Soon, however, unfavourable economic consequences become obvious, along with the characteristics of the new government: it is as incompetent and corrupt as its predecessors, and likewise favours the organized interest groups. After the change of administration, political rivals privatize, promising new national unity and well-being for all - and so forth.

The model advanced for the developing countries and their extractive industries by Chang et al. (2009: 3) rests on similar factors: "The basic trade-off is given by equality versus efficiency. Greater equality is obtained under public ownership of a national resource, while larger efficiency occurs when ownership and administration of the resource is private. The connection between ownership and the equality-efficiency trade-off is given by the set of incentives for work effort that each regime elicits from households". The trade-off depends on many external and internal factors, first of all on the world market price of the commodities (raw materials), and on 
the tax system and quality of governance of the country. According to the model, privatization increases efficiency, but also inequality. The latter makes nationalization more likely, especially if prices are rising and the government cannot centralize the additional income due to a poor quality of tax system or of contracts. If prices fall while the economic performance of the public firm deteriorates, the next turnaround begins - towards privatization.

Regarding the developed countries, the presumption of nationalization-privatization cycles has been missing for a long time, but the need to explain the shifts between public and private ownership was felt already in the 1960s. The early studies emphasized mainly socio-cultural motivations, sometimes adding the economic reasons.

Pioneering works in property-rights theory, based on the bounded rationality and opportunism of individuals, ${ }^{8}$ wrote primarily about common (not state) ownership. Demsetz also starts from social preferences. Property rights change, he states, "when the gains of internalization become larger than the cost of internalization... A proper interpretation of this assertion requires that account be taken of a community's preferences for private ownership... But, given a community's tastes in this regard, the emergence of new private or state-owned property rights will be in response to changes in technology and relative prices" (Demsetz 1967: 350). Later he emphasizes the role of specialization, influenced by technological progress, and brings political aspects into the analysis. He shows fluctuations in a comprehensive historical overview from the Stone Age until recent times: productivity-enhancing specialization, based on extensive private property, was halted first in the medieval times by uncertainty and higher risks in trade, and then, from the second half of the nineteenth century by state regulation and redistribution. "Regulation directly limits the influence of private owners on resource allocation; wealth redistribution indirectly does the same" (Demsetz 2002: 669). These phenomena are not equivalent to increasing state ownership, but the two developments are basically parallel. They are also influenced by the outcome of specialization, which promotes private ownership, but concurrently "has itself, in its secondary effect, limited the robustness of capitalism... Specialization also limits the scope and extent to which the consequences of private ownership are socially tolerated" (pp. 670-671). Specialization and market empower pressure groups, urging protectionist measures and redistribution - Demsetz argues, similarly to Polanyi. Likewise, he states, the increase of several types of risk may have a dual effect on the property structure.

The spread of risks is central in the works of Armen Alchian, one of the founders of the property-rights school. Exceptionally among the early representatives of this theory, he addresses not only common ownership, but state (or municipal) ownership, stating that when these types of public property are transferred to private hands, the method of achieving governmental goals changes: "When 'we' do not want (whatever that means) these changes to occur, these activities are conducted via public ownership instead of privately... To the extent to which 'society' reduces risks that must be individually borne and instead has them borne by society at large... the greater is the extent of public property" (Alchian 1965: 828-829). He admits that the questions of real choices and the effects of voting or decision-making processes still remain open.

${ }^{8}$ See e.g., Furubotn - Pejovich (1972) and Williamson (1996). 
From the late 1980s onward, the explanation of fluctuations divides into two branches, emphasizing either political or economic motivations.

\subsection{Politico-institutional analyses}

The basic assumption of the theory of public choice, shared also by most schools of new institutional economics, is that bounded rationality and pursuit of self-interest holds for politicians, too. Just like the economic agents, they also seek to maximize their own benefits and prefer power aspects over economic efficiency (Stigler 1971; Williamson 1996). So, in a democratic system, one characteristic of state ownership is the inherent uncertainty of property rights. The other special feature is that the principal-agent problem appears not only in the owner-manager relationship, as Jensen and Meckling (1976) showed, but in the relationship between politicians and their voters. These are the two starting points for the following theories.

The thesis on the uncertainty of state ownership was perhaps formulated first by Jürgen Backhaus, who attributed the uncertainty to democratic elections. "Public enterprises differ from private enterprises in only one crucial respect their ownership is of limited duration...The democratically elected government and the duration of ownership coincides with the current term of the sitting cabinet" (Backhaus 1989: 310). That is, this type of ownership constitutes a special form of usufruct. Considering the institutional conditions of democratic alternation, no government can take the responsibility for the measures of its successors, thus it is doubtful or even impossible to make credible commitments for the long-term decisions. ${ }^{9}$

Backhaus attempts to explain nationalizations and privatizations, and their fluctuation, in a single coherent framework. (There are no cycles, he argues, only because the length of the distinct periods is unsteady.) The verbal model, built on two parties and two goals - rising employment and the opportunity for discretionary decisions ${ }^{10}$ - shows that for the public companies "... successive policy changes will lead to public enterprises being less and less suitable for almost any conceivable governmental task. At this point, they become ripe for privatization" (Backhaus 1989: 325). Selling state property maximizes budget incomes in the short run, and deprives the next government of ownership utilization of all kinds. On the other hand, he states, the need for public firms is long-lasting, and so their group expands from time to time, through the founding of new companies, acquisition of ailing firms, or pursuance of open nationalization programmes. (Note, the coherence of the model is breaking down at this point.) The reason behind mass movements appearing at the same time and forming waves, is that the economies of scale of ownership change: the political unit cost of selling or buying firms is less if several transactions are carried out simultaneously.

The theory of Andrei Shleifer and Robert Vishny supposes that governments aim to extend their control as far as possible by regulation or ownership, so reinforcing their bargaining position. But why, then, the authors ask, do they bring themselves to privatize.

The decision to privatize "becomes the outcome of competition between politicians who benefit from government spending (and bribes) and politicians who benefit from low taxes"

\footnotetext{
${ }^{9}$ On credible commitment, see e.g., North (1990), Przeworski (1997) and Stiglitz (2001).

${ }^{10}$ According to Backhaus, the third traditional goal, to realize regular income from state-owned firms, became less relevant in the modern economies because of the low profitability in the public sector.
} 
(Shleifer - Vishny 1994: 1022). Thus, privatization usually occurs when the conservative governments, favoured by taxpayers, come to power, or the democratic governments replace the communist ones. The other determinant of such decisions is the chance to gain political benefits from public ownership. "The greater the independence of public firms from politicians, the less attractive is public ownership to politicians" (Shleifer - Vishny 1994: 1023). The likelihood of privatization grows when it is important to decrease government spending. This strengthens the position of the Treasury or finance minister in their bargaining with "spending" ministries, just as a strict monetary policy does (Boyco et al. 1996). Finally, the pro-state ownership arguments are weakened by recognition of the adverse effects of political influence, by the growing importance of innovation, and by the presumption that contracting out services - or more generally by privatizing firms - result in the improvement of product quality (Shleifer 1998).

Another paper co-authored by Shleifer reverses the above question: why does privatization remain limited? The analysis uses the term privatization in the American sense, for contracting out public services. Lopez-de-Silanes et al. (1995) analysing data from 3,000 municipalities between 1987 and 1992, tested three types of motivation for public-service provision vs. contracting out services: efficiency (social goals), ideology (attitude towards the role of government), and political patronage. Their model showed that all three motivations had some effect, with patronage in the first place. The likelihood of contracting out (i.e., privatizing) increases if "clean government" laws are enacted, labour unions are weak, and the budget constraint of public firms is hard. Politicians give up patronage when benefits gained from public provision are too low, due to the institutional conditions, or they become politically expensive due to the high taxes or an excessive budget deficit. "The privatization decision is determined to a significant extent by the trade-off that politicians face between inhouse provision of public services, which brings them political benefits, and higher government spending causing them political costs" (Lopezde-Silanes et al. 1995: 25).

The importance of laws and institutions is underlined in the model of Glaeser, which starts from the historical examples and draws up an excellent case study on public services in New York City. According to this analysis, public (municipal) ownership or provision of services expanded in the United States due to the disadvantages of contracting out: under-pricing of inputs bought from the government, overpricing of outputs sold to it, and perversion of subsidization by corrupt bargains. The author is, of course, well aware that public ownership does not eradicate corruption and has other drawbacks, primarily over-employment. However, states are changing: "Within the U.S. and most of the developed world, the weapons against corruption are much stronger today than they were in 1900 (...). As such, the corruption-eliminating advantages of public ownership have diminished steadily within the U.S. and anywhere else where corruption is limited" (Glaeser 2001: 41) - which makes privatization justified and possible.

Finally, Bortolotti - Milella (2006), in their qualitative analysis, advocated the combined effect of fiscal and institutional conditions, assuming cyclical fluctuations even in Europe: the "big privatization wave of the 1980s and especially 1990s has mostly been a cyclical phenomenon, where the engine of sales have been booming stock markets, and worsening fiscal conditions. However, within this common trend, the extent to which governments privatize depends upon exogenous political and institutional determinants, which tend to persist in the long run" (p. 30). The main element of these determinants is the type of democracy, its 
consensual or majoritarian form. The latter is more favourable to privatization due to the weaker veto power of the political minorities.

\subsection{Is a purely economic explanation of fluctuations possible?}

Despite political or ideological arguments to the contrary, "a purely economic theory of nationalization and privatization is conceivable, on the basis of an analysis of government, as a rationally discriminating operator acting as the agent of pressure groups competing for redistribution," stated Rosa (1993: 334), who attempted to explain the timing of changes. However, even the statement quoted above brings doubt whether this is a purely economic approach: the formulation refers to the political agency and public choice theories, as the author himself admits. Yet within this framework, he builds up a model based on the modifications in the economic and financial parameters, and concludes that "through nationalization and privatization episodes, politicians, after all, do behave according to economic rationality" (p. 335).

Rosa argued that nationalization is a voluntary market transaction for private investors seeking to gain financial wealth. On the other hand, governments try to maximize political support by redistributing wealth among voters according to political pressure and to the opportunity cost of alternative measures. The means of redistribution may be regulation, taxation (or debt-financing) and cross-subsidies via state-owned enterprises, for "rational government decides to expand the public sector when the benefit/cost ratio of transfers managed through public firms exceeds that of transfers through current taxes-subsidies or of regulations" (Rosa 1993: 320). Government competes for the ownership of enterprises with private shareholders. The winner is the one who values the firm highest, taking into account that the cost of capital differs for the two - the state may raise taxes to finance the deal. So, the question of spreading or shrinking public ownership is decided by the relations between interest rates and the costs of taxation. To put it simply, if marginal costs of taxation rise, government values the firm less than the private investors, and privatization occurs, while rising interest rates lead to nationalization, as government may also use tax measures.

These macroeconomic determinants explain how the waves of privatization/nationalization develop. Players do not react to smaller fluctuations, wrote Rosa, without providing an estimate of the extent needed for starting changes. He explained the existence of the mixed economies by the intention of both actors to buy firms with significant market power (monopoly rents); and with small enterprises transaction costs jump too high. Moreover, public debt or taxes might be reduced from privatization incomes, affecting the marginal costs and equilibrium points.

The competitive bidding model, including data from 9 West European countries between 1963 and 1985, did not refute these hypotheses. In a paper with Pérard published in December 2008, Rosa refined assumptions and repeated the calculations for 8 countries in the period of 1988-2002. Results differed in the sense that the costs of taxation did not prove significant - we may suppose partially because of operationalization difficulties. ${ }^{11}$ From this the authors concluded that the "private investors are the main agents of rationality in the competition for ownership since the variables that directly affect their behaviour are the ones that effectively determine the observed changes of ownership of firms during the last few decades" (Rosa -

\footnotetext{
${ }^{11}$ These costs are measured by tax receipts as a percentage of GDP, which is hardly the most accurate indicator.
} 
Pérard 2008: 20). The sharp increase in the cost of funds for private investors explains the new wave of nationalization after the stock-market crashes in 2008, they claimed.

Regardless of whether we agree with that statement or not, it is certain that the extension of state ownership after 2008 raises sharply a delicate question hiding behind all the above analyses: is privatization reversible? It is hardly surprising that the governments in Latin America, where ownership cycles are most obvious, saw it as important to stress that privatization "is irreversible... no power on Earth can change it," as Chua (1995: 225) quoted the Prime Minister of Jamaica. In the 1990s, during the big wave of selling state firms, representatives of international organizations also declared: "The present interest in privatization is no fad... The public enterprises were unable to meet all their ambitious goals; instead, they sometimes undermined the very objectives they were created to serve... Lessons have been learned, however, and today's strategies reflect these lessons" (Shirley 1992: 31-32). The stable direction is important not only from a theoretical point of view but also considering the aim to build certainty and confidence among investors, by demonstrating the credible commitment of the host governments. Although at the turn of the millennium, most experts would have agreed with Toninelli (2000) in supposing that privatization seems irreversible, subsequent developments showed that the extensions and methods of state intervention might fluctuate substantially. ${ }^{12}$

\section{OPEN ISSUES}

The varied explanations for the alternation of nationalization and privatization, presented in Section 2 are interesting and, in some cases insightful, but they are divergent. Which of them is most acceptable? Let us look at their values, shortfalls and the possible objections.

Explaining the turnarounds through oscillations in social preferences, individual and collective evaluations, efficiency and equality, especially in a Polanyian way, i.e., building on social changes rather than personal attitudes, seems to be promising. We can apply it to the property relations, if nationalization is taken as a move towards collective values and equality (retaining employment, controlling inflation or management of incomes), and privatization as advocating personal initiative and higher efficiency. The extensibility of these general principles gains further support from the fact that the risk-sharing approach of the early property right school authors might be included in this framework.

This attention on the changes in the role of the state, which is closely connected to nationalization and privatization, is an important advantage of the "oscillation" approach. Yet it is not designed to explain the specific conditions, timing or method of the ownership changes. The models of Chua (1995) and of Chang et al. (2009) also build on the variation in the relative values attached to efficiency and equality, while drawing into the explanatory field of the sociopolitical conditions (ethnicity, quality of governance) and concrete economic factors (market demand and prices, tax system). However, both studies deal with the developing countries, and within them most with the raw material-producing industries. Chua explicitly asks whether her

\footnotetext{
${ }^{12}$ Later Toninelli also revised his position, noting that "history has always been characterized by the continuous alternation between phases of extreme state activity and reactions in the opposite direction" (Toninelli 2008: 690).
} 
model can apply to all regions, or at least provides lessons for those with their own socio-ethnic groups, such as post-socialist East Central Europe ${ }^{13}$ or over a longer historical period to the developed countries, though nationalism there has a different meaning, she admits. Let us add that the whole social context differs too. That is why it is worth limiting such analyses to similar historical-social formations and relatively homogeneous groups of countries.

One main lesson learnt from the analyses covering the developing countries is the usefulness of the multi-factor explanations. The combination of economic and socio-political elements is also widespread in the property law school and among institutionalists. ${ }^{14}$ Interestingly, the models that view political forces as decisive, seldom include ideology, or rather the political orientation of the governments. Of those quoted, the exception is the paper of Shleifer - Vishny (1994), which states that the left-wing governments tend to nationalize to gain from public spending, while the right-wingers privatize to gain from the lower taxes their voters prefer. The novelty is at most in the line of argument. The thesis itself is accepted by the majority of the analysts, on grounds of the parties' value system. Economic history shows this is the main tendency, but it may differ under specific conditions.

Looking at the examples from several countries and periods, the left-wing parties did not nationalize or hardly so in Britain or France in the 1930s-1940s (Millward 2011), and this was the characteristic for Sweden and the Netherlands for even longer periods (Carlsson 1988; Davids - van Zanden 2000). Moreover, these parties sometimes initiated the wave of privatization: the first such move in Britain was made by a Labour Party government, before Margaret Thatcher, when British Petroleum was partially sold in 1976 (Parris 1985). Nor when it returned to power in the 1990s did Labour reverse the process, despite what it had said in the opposition (Parker 2013). Likewise, the Socialist Party of France started major nationalization in the late 1980 s, but thereafter in the 1990s the socialist government carried on the privatization programme of its predecessors (Somai 2016). When the socialists gained power in Portugal in 1995, they too sped up the sales of the nationalized enterprises (Parker 2003), while Hungary's socialist government in 1995 began widespread privatization of strategic firms, public services and banking (Mihályi 2010). Meanwhile there were cases of nationalization by the right-wing regimes. In France in the 1970s, several big steel firms and an aircraft company were taken into public hands (Walters - Monsen 1981). Elsewhere there was a hesitation about privatization: the right-wing state governments in Germany in the 1980s seemed to believe in "state capitalism" and rejected privatization, backed by the heads of corporations concerned (Esser 1989).

These cases prompt several observers to see the governments' ideological direction as inconclusive. A historical analysis by Millward (2011: 12) states only of the 1950s that in Western Europe "public ownership had emerged in a variety of ideological settings - socialist, fascist, pro market". According to Willner (2003: 61), "The motives for public ownership have often been pragmatic [rather than ideological - É. V.], and it has sometimes been implemented by non-socialists." Bortolotti - Pinotti (2003) concluded from the sales in 21 developed countries between 1977-1999 that the ideological stance of the parties in power did not correlate with the propensity to privatize, affects only the methods they used.

\footnotetext{
${ }^{13}$ Her examples include attitudes to Jewry, the disintegration of Yugoslavia, and post-independence history in the Baltic states.

${ }^{14}$ For instance, Demsetz $(1967,2002)$, Backhaus (1989) and Bortolotti - Milella (2006).
} 
Returning to the politico-institutional approaches, what they lack most is an account of why ownership changes take a mass form in certain times and places. The explanatory factors found in them are institutional features that differ even among the European countries: type of democracy (majority or consensual), strength of trade unions, management system of state corporations (degree of independence from government, hardness of budget constraints), quality of administration, and high or low corruption probability. If the ability of the developed countries to curb corruption is improving, as Glaeser (2001) claims as one argument for privatization, why does nationalization keep returning, after 2008? Indeed, these factors change only slowly, and so cannot explain the frequent switches in the ownership structure.

The models described as purely economic are problematic not only because they rest partly on political-agency theory (as the papers of Rosa and Perard) but because their parameters chosen, the interest rate, fluctuates too much and seems to be too short-term. By no means all fluctuations are tied to a turnaround in the direction of ownership change, as authors themselves point out - but they do not even try to quantify "bigger" changes that lead to reactions concerning ownership structure. The same applies to the reasoning of Bortolotti - Milella (2006), who added to the political explanatory factors the state of the stock market and of the central budget. This also raises the question of whether a flourishing stock market causes privatization, or the opposite occurs, with news of prospective share sales in the state-owned firms pushing the stock market up.

Rosa - Perard (2008) argued that the rising capital costs (interest rates) for private investors bring nationalization while a fall in them leads to privatization. This approach cannot explain the simultaneous occurrence of waves in different countries, since the moves of interest rates or other capital costs may vary, according to the position of the currency and the country risk. Moreover, interest rates almost never rise during the economic recessions, because of the supply-demand dynamics and monetary policy efforts to boost economy. But if interest-rates fall in the times of crises, that, according to the model, would always lead to privatization, while economic history does not support this assumption. The referred paper attributes the return of nationalization after the stock-market crash of 2008 to increased capital costs. Nevertheless, statistics showed that interest rates fell sharply both in the U.S. and in Europe after mid-2007 and autumn $2008 .^{15}$ Thus the nationalization wave is not really explained, neither is the difference between the two regions in privatization commitment. ${ }^{16}$ In addition, the authors see the processes being led mainly by the private investors. Yet on the one hand, governments, in pursuing their property-objectives, may influence the costs and so the behaviour of the market actors by monetary policy. On the other hand, governments are not autonomous actors either: crises affect their costs (conditions for taxation and borrowing). The picture is certainly more complex than the elegant model suggests.

In conclusion, none of the theories on the mass appearance of nationalization and privatization can offer a comprehensive explanation. They fail to make it quite clear why the large waves, coordinated in time and space appear, what determines their direction, and why the

\footnotetext{
${ }^{15}$ https://www.ecb.europa.eu/stats/policy_and_exchange_rates/key_ecb_interest_rates/html/index.en.html and https:// www.macrotrends.net/2015/fed-funds-rate-historical-chart

${ }^{16}$ Privatization of the rescued banks was quick in the U.S. while it proved rather slow in Europe (see Megginson (2017) and Voszka (2017) for details).
} 
earlier homogenous trend broke down after 2008. The following section cannot offer a final explanation either, it is just an attempt to give a new framework that rests on elements of the earlier analysed proposals, combines them, and stresses the often implicit assumptions and components.

\section{A PROPOSAL: THE DECISIVE ROLE OF EMERGENCY SITUATIONS}

I will argue that wars and crises play a decisive role in forming the nationalization and privatization waves. Emergency situations (in short crisis, but including also armed conflicts) seem to be suitable starting points for answering the open questions. It is useful to follow the analyses described in Section 3 in considering the economic and socio-political elements together as a multi-causal motivation, and in taking into account the correlation among ownership changes and the transformation of the role of the state.

An integrated framework. Fluctuation or changeability in a phenomenon assume implicitly that each part can be placed in the same frame as its opposite. ${ }^{17}$ In our case it means that the nationalization and privatization waves should have important common traits in the Europeantype societies of the 20 th-21st centuries:

1. these are massive changes in the ownership structure,

2. they arise in exceptional situations, based on political decisions,

3. they are linked with quests regarding the whole socio-economic settlement and changes in the form of capitalism (in the Eastern regions of Europe with radical transformations of the system),

4. despite their opposing directions, the aims, formulated on a high level of abstraction, are similar, ${ }^{18}$ and

5. both promise advantages to all groups in society - except for radical, forceful systemic change - so that at least temporary consensus can be formed around either direction (Voszka 2017).

The extraordinary situation as motivation and opportunity. The central role of crises in the ownership changes is not fundamentally new. Several authors consider war and crises as starting points for ownership change, but few unfold the mechanism of their impact or the reason why even the property issue comes to the fore. ${ }^{19}$

General crises comprise of social, economic and political factors which provide actors and motivations for transformations in social attitudes, as well as in institutions. Let us first see how they form the basis for such radical processes like the big waves of nationalizations and

\footnotetext{
${ }^{17}$ This point is mentioned explicitly in Backhaus (1989).

${ }^{18}$ The declared aims in both cases are to foster development and modernization, improve competitiveness through governmental or private investment, restore financial equilibrium by curbing subsidies or gaining funds from share sales, to increase welfare and thereby the stability of political power - see also the general reasoning summarized in the introductory part. The similarity in aims was stressed also by Chua (1995).

${ }^{19}$ On the role of crises see e.g., Aharoni (1986); Wengenroth (2000); Toninelli (2000), Berend (2006); Bortolotti - Milella (2006) and Millward (2011). The way crisis transforms the ownership concept is excellently analysed by Davidson Dyal-Chand (2011), whose focus on how property theory shaped legal aspects in the United States, offered useful lessons for the recent analysis.
} 
privatizations. A distinction is drawn in institutional economics and political science between slow, gradual transformation and "revolutionary" critical junctures. ${ }^{20}$ The latter forces decisionmakers (politicians) to act when facing "extraordinary uncertainty and demands from publics to do something" (Farrell - Quiggin 2012: 5). Such crises offer a chance, not just a motive, partly because sweeping uncertainty weakens the existing institutions and traditional norms, loosening the tight intellectual and power barriers of a "peaceful period". So, decision-makers have wider room for manoeuvre and loosened path dependency: the hitherto impossible becomes possible or even inevitable (Friedman 1962). This goes for property too: "Struggles over oppositional visions of property... tend to reach critical turning points in moments of political and economic crisis" (Davidson - Dyal-Chand 2011: 103).

Political decisions and the role of the state. The concept just quoted also contains a second important element: critical situations - irrespective of their origin, be it the economic, social tension or even armed conflict - require a political solution through political decision-making, thus state involvement is essential. No individual person or economic actor can manage to avert collapse, combine forces, restore trust, or maintain operability.

The connection is still clearer with ownership. Defining and protecting property rights is the task of the legislative and executive powers of the state. Nor can the state ownership be dissociated from the state itself. It is certainly involved in nationalization or privatization as seller or buyer, and in addition it must provide the frameworks: create formal and informal rules of the game, win over support groups and public opinion, and disarm opponents. The task of building a coalition is far from simple, because transforming ownership, even if only in a part of the economy, affects deep layers of the socio-economic order. Redistributing chances of wealth and income may offend many different interests.

The property issue is embedded in the whole role of the state; crisis makes the relationship even more obvious: "Economic and social crises tend to generate a more diffuse discourse, with property as just one element of a larger conversation about the nature of the market and the role of the state" (Davidson - Dyal-Chand 2011: 132). The great waves of nationalization and privatization mean much more than just a change of owner. If not to the same extent and uniformly in all countries, they are interlinked with greater or smaller transformations in the socioeconomic system. The developed regions displayed modifications in the form of capitalism. Wars brought about a war economy based on strong state intervention, and the slump of 19291933 questioned the viability of the free market system. Individual countries gave quite different responses, but whether we view attempts at dictatorship or efforts to salvage democracy and the market economy, the main direction of change, paradoxically, was state intervention, including expansion of public property. This applies to America's New Deal as well, designed to brutally expand aggregate demand, when SOEs were created with huge federal investments and loans from the (state-owned) development banks. Swedish, French and Dutch social democrats in the 1930s looked for new approaches and institutions to boost collective aspects rather than individual ones, as did the welfare states after the Second World War. At the turn of the 1970s and 1980s, privatization appeared as one of the main pillars of the new theoretical and economic-

\footnotetext{
${ }^{20}$ For instance, North (1990), Capoccia-Kelemen (2007) and Morgan et al. (2010).
} 
policy paradigm, ${ }^{21}$ neo-liberalism. Meanwhile, radical transformation was typical on Europe's peripheries. In the Soviet Union from 1917 and in Eastern Europe after 1945, creating a state ownership dominance was among the key elements in constituting the foundations of socialism, just as privatization was considered as decisive for regime change after 1990.

The embeddedness of the property issue in the systemic changes or at least in the modification of the form of capitalism provide explanation on what scale and type of crises lead to the privatization/nationalization waves. Comprehensive realignment is not required for plain shortterm cycles; only when there are shocks to the whole socio-economic system there is sufficient motive. (It is not always clear right away how big a crisis is, and politicians may well dabble with the less radical measures first.) It is often a matter of political resolution to decide when to declare the situation exceptional and so legitimize the introduction of the extraordinary methods. $^{22}$

Why property? Why does altering the extent of state ownership play an important role in the crisis management, when it involves the high political costs of crude intervention in the economic and social fabric? The answer is quite simple in the case of wars or sweeping system changes: by doing so politicians declare the extremity of the situation and their commitment to apply radical solutions. In less extreme cases, politicians, specialists and stakeholders usually have difficulty in working themselves up to a significant rearrangement of public ownership. Instead of nationalization, they may prefer to try involvement of private capital through mergers, formal or informal cooperation between government and companies, subsidies of various kinds, or possibly stricter regulation to push private firms toward pursuing government aims. Alternatives to privatization may include reorganizing state-owned firms, or marketizing their activity, for instance by cutting subsidies or loosening regulation to give them greater room for manoeuvre and better profit prospects. In other words, altering regulations may attain much that governments expect of ownership changes: the two methods may substitute each other.

The basis for substitution is that the regulatory frames alter the content of property rights. For ownership is not an indivisible, physical unit, but a bundle of rights that could be constrained by various means, including regulation of markets, progressive taxation and planning, partially transferring control to the government/society. ${ }^{23}$ In cases of extreme danger, preparation for changing the system may involve "emptying" private property by erecting curbs that leave the ownership role as formal or nominal: the state's political institutions may take over the main decisions, from distribution of production factors, through investments and price-setting, to wage control. (See as examples the war economy in Hitler's Germany or in the East Central European countries during the transitory years before total communist takeover after the World War II.) But the reverse may also occur: if firms in public hands must really operate under tough market conditions that may "empty" the state ownership, altering its essential features. This has been attempted in recent years by several countries, from Sweden to France.

\footnotetext{
${ }^{21}$ The expression "theoretical paradigm" is used here in line with Kuhn (1962). Such changes are often accompanied by the transformation in the economic-policy paradigm as well.

${ }^{22}$ These dilemmas are described by Bernanke (2015).

${ }^{23}$ This "onion skin" theory was expounded in the early 20th century by Karley (quoted in Berman 2006). Mises (1922/ 1951) takes a similar approach and so does the property rights school.
} 
Modification of the ownership structure occurs if such alternative methods prove to be ineffective, or decision-makers feel there is no time to wait for them to unfold, or perhaps that the alternatives would have even higher political costs. For instance, reorganization or subsidization of the state-owned companies does not provide a solution, or the public feels less antipathy toward tax revenues being used to save the companies if it goes with stronger control, i.e., taking them into public hands. Moreover, nationalization and privatization are relatively simple technically - less sophisticated than regulation and may bring faster rewards, which is notably important in the times of crises. Ownership change is a visible, usually well communicable action, ${ }^{24}$ which is essential for public support.

Consistency in time and space. Concentration of the changes in time is explained partly by initial conditions. Crisis management can work only if the scope of ownership transformation is large enough. The means of persuasion and implementation, including propaganda techniques and the organization of the process by the governmental agencies, have their economies of scale: bigger quantity cuts political and fiscal unit costs. As regards spatial coordination, it rests on the global nature of the crises (and wars), at least those involving Europe and the United States. The predicaments of various countries, the similarity in their problems and objectives provokes similar reactions, strongly encouraged by direct and indirect influence of regional integrations and international organizations. ${ }^{25}$

Ownership change also displays the spreading mechanisms found in the institutional analyses of other areas: imitation and learning, competition and outside compulsion (or at least influence) ${ }^{26}$ Spatial and temporal concurrence are inspired first by other economies' successes and failures, which back the arguments and positions of the insider politico-economic groups acting in the same directions. Secondly, a part is played by competition among trading partners. When other states give a boost to their firms with subsidies and/or government contracts, private firms in a poorer background fall back and it is worth taking them into the state hands. But when loss-making public firms bound by bureaucratic procedures must compete on the open market with strong private companies, while international agreements restrict state subsidies, there is no use in delaying privatization. Thirdly, the environment often has a direct influence. Hitler's Germany seized factories or set up state-owned firms on conquered territories. The Soviet Union also expropriated firms in its influence sphere, then ably urged nationalization as a basis for the new political system. Integration in Western Europe followed the principle of neutrality regarding property structure, but the ban on state subsidies weakened the positions of public firms. The steps toward the single internal market and liberalization, along with the obligations concerning budgetary equilibrium and state debt, gave strong incentives to privatization in order to cut loss-compensatory spending and obtain additional income.

What direction of change? Spreading mechanisms may influence the dominant direction but this is only an external factor. The national course is basically explained by the embeddedness of ownership changes into the prevailing concept of the role of the state: nationalization goes with advancing state intervention, privatization with decline in it. This is the reason why there was no

\footnotetext{
${ }^{24}$ The waves following 2008 are exceptions to this point too, to which we will return later.

${ }^{25}$ Consider for instance the influence on the Central-East European countries' privatization by the European Union, the World Bank and the IMF in the 1990s, based on the "Washington Consensus."

${ }^{26}$ For a summary, see Campbell (2010) and several other chapters in Morgan et al. (2010).
} 
turnaround between the early 20th century and the early 1980s, when the growing role of the state (in various ways and to varying degrees) spread in the developed countries. However, the first response to the oil crises of the 1970s - extending state intervention and ownership proved just a short-term emergency solution. By the end of the decade the whole state sector became a loss maker, mainly due to politically motivated decisions to bail out failing private companies by taking them over. That is, nationalization, seen hitherto as a panacea, in the new crisis could not block recession or curb unemployment and inflation, while it contributed to the imbalances and indebtedness on the macroeconomic level. That is, crisis management itself fell into crisis, and this was the very reason for seeking new solutions in the 1980s, namely, privatization.

Explaining the specific nature of the post-2008 wave. The increase in the number of ownerships changes itself might be explained with the same precondition as former waves: an exceptional situation. The question is, why the previously uniform direction had fallen apart.

As a first reaction to the crisis, the governments of the developed countries, threatened by the domino effect of the bank failures, the collapse of the global financial system and by the deep recession decided to bailout the big banks by recapitalization from public funds, exercising also ownership control over them. This process started in disguise. Public ownership often occurred in the forms of preference non-voting shares, warrants or other securities. Politicians both in the U.S. and in the European Union spoke about buying impaired banking assets or share options they avoided mentioning nationalization of financial institutions. However, bailouts spread in several other sectors (firstly in automotive industry) alongside the techniques of "quiet nationalizations" ${ }^{\prime 2}$ like indirect public ownership, founding new subsidiaries by state firms, and portfolio equity investments by governments or state-owned banks. Re-municipalization of firms and activities, i.e., bringing services back in-house to local governments also occurred frequently. ${ }^{28}$

On the other hand, the return of the banks to private parties started quickly in the U.S., and at a much slower pace also in the European countries. This re-privatization was supplemented by other privatizations, often accompanied by the austerity measures, on the grounds that budget deficit and sovereign debt, partially ballooned by bank bailouts, might be reduced by proceeds from sales revenues. ${ }^{29}$ Here again, quiet forms appeared like selling subsidiaries or minority shares of the state-owned companies.

Because of these processes, during the worst years of the financial crisis, both nationalization and privatization jumped up to an unprecedented height and appeared parallelly in several countries. To be sure, aggregate data on a global scale showed some signs of parallelism even previously, but the volume of changes increased significantly in 2008-2009. While privatization decreased after the turn of the century, nationalization began to rise from 1998 onwards. ${ }^{30}$ The

\footnotetext{
${ }^{27}$ The term "quiet nationalization" and "quiet privatization" has been used for long, see Walters - Monsen (1981) and de $\mathrm{Ru}$ (1986).

${ }^{28}$ For details see e.g., Megginson (2013); Guedhami (2013); Pigeon et al. (2012); Hall (2012); Megginson (2017); Voszka (2017).

${ }^{29}$ Megginson (2010); Bartsch-Ng (2010). Privatization after the crisis is also analysed by Demetriades et al. (2010), Visvizi (2012) and Bräuninger (2013).

${ }^{30}$ Note, this is the year of the Asian crisis. The expansion of public ownership is partially due to the growing activity of Sovereign Wealth Funds and other state enterprises of the BRIC countries (Bortolotti et al. 2010; Megginson 2017).
} 
ratio of the latter to the global GDP, however, remained around 0.2 per cent, reaching the peak of 0.5 per cent in 2009 (while privatization oscillated between 0.1 and 0.3 per cent in the same period, coming near to 0.5 per cent also in 2009). ${ }^{31}$

What is the background of the parallel, large scale expansion and shrinking in state ownership? Contrary to the previous waves, neither politicians nor analysts labelled nationalization as a panacea. The traditional crisis management method itself fell into a crisis again, just like in the late 1970s, but now it was impossible to argue convincingly for privatization. Neither course was popular: the public saw nationalization as giving rewards to the irresponsible decision-makers, acknowledging moral hazard and socializing losses, while it expected privatization to result not in economic stimulation, reduced taxes or a chance to buy shares, but in higher prices, growing unemployment and inequality. Good arguments could be made for the statement that regardless of whether the state buys or sells, the bill lands on the taxpayers and consumers. The transaction costs are certainly high in any case. Both directions of ownership change meet incredulities drawn from the daily experiences and the arguments of the opposing camp among specialists and politicians. ${ }^{32}$

As with the former waves, the discussion goes far beyond the nationalization/privatization issue, to touch on general views on the role of the state, reopening theoretical and political debates on the need for a new form of capitalism. When the crisis broke out, there was an agreement on extending state intervention, but the consensus soon fell apart (Farrell - Quiggin 2012). Neoliberalism had been shaken, but despite several attempts, ${ }^{33}$ there is still no generally accepted new paradigm. This is the very reason why the previously uniform direction of big waves in ownership changes has been broken up: neither nationalization nor privatization has a universal approval, the economic-policy (and theoretical) paradigm as the background of ownership waves has been rendered uncertain.

\section{CONCLUSIONS AND PERSPECTIVES}

As I have tried to show, focussing on the exceptional situations may help to answer questions left open by earlier research on the 20th century and recent ownership changes in the Europeantype societies. Looking at nationalizations and privatizations in an integrated framework, deep socio-economic crises create both sufficient motivation and opportunity to give impetus to the "moments" of state ownership. In a political decision-making process, this tool of crisis management is chosen because it demonstrates the commitment of politicians to apply radical solutions, and because it is rather simple technically, bringing faster rewards than the alternative methods. Extraordinary situations explain the emergence of big waves, as crisis management can work only if the scope of the realignment is large enough, and the process also has some economies of scale. Spatial coordination rests on the global nature of the crises, the similarity of the problems and objectives in different countries, and it is encouraged by the influence of

\footnotetext{
${ }^{31}$ Voszka (2018), based on the data form Megginson (2013, 2014).

${ }^{32}$ For an excellent summary of these views and debates see Bernanke (2015), on the public attitudes concerning privatization Denisova et al. (2011).

${ }^{33}$ One of the main concepts is state capitalism or the entrepreneurial state, see e.g., Bremmer (2010), Mazzucato (2011) and Musacchio - Lazzarini (2012).
} 
regional integrations and international organizations. The direction is basically explained by the embeddedness of ownership changes into the prevailing concept of the role of the state: extension of public property goes with advancing state intervention, privatization with decline in it. This is the reason why there was no turnaround between the early 20 th century and the early 1980s, when strong state involvement was dominant even in the developed countries. The trend was reversed when the crisis management by state intervention and nationalization itself fell into a crisis, having proved inadequate to remedy the economic and social turmoil. It was the very reason for seeking new solutions in the 1980s, namely, neo-liberalism and privatization. A similar situation occurred in the late 2000s: the crisis of crisis management appeared again. One characteristic of this wave, the break-up of the homogenous direction, is rooted in the growing uncertainty of the economic-policy (and theoretical) paradigm as the background of ownership changes.

Considering these new developments, what might be the future of ownership transformations? One possibility is a change of paradigm in economic policy and, linked with it, in property issues. The conditions are there: the crisis-shaken developed world has lost faith in the former economic policy and dominant theory that fail to predict, reflect or resolve the problem. This creates demand for new solutions and political willingness to accept them. This option is supported by historical precedents: the turnaround appeared in the 1980s, when crisis management itself got into crises. Conversely, a whole decade since the crisis began, all approaches or visions that could be professed as advantageous to all social strata or strong interest groups are faint.

The other prospect is the continued fluctuation between individual and collective values, a self-regulated market and state intervention, perhaps bringing back earlier approaches in a modified form. It would not exclude a long-term tendency for market relations to deepen and spread ever wider - in terms of the present analysis of privatization in a broad sense - which might be blocked by the opposite tendency only temporarily (as suggested e.g., by Streek 2010). Based on this view, the events after 2008 can be understood as a provisional recoil - a theory backed by the recent rapid turnaround in direction.

Yet this very experience can serve as an argument against assumptions of paradigm change and recurrent fluctuations alike. The rapid turnarounds might be interpreted as a sign of failure: both well-known solutions lost credibility in politics, public opinion and theory. More or less state intervention, more or less public property? In dual models, with rigid categorization and a quantity approach, there seems to be no good answer to these questions.

Thus, it is worth considering the third possibility: to give up the dichotomous approach. This recalls the old debate on whether ownership itself is decisive, or whether it should be closely linked to regulation and to state behaviour in general. Theoretical views questioning the dichotomy have long not been exceptional. As we have seen, they underline that private property rights may be constrained by various kinds of state intervention. According to Laffont - Tirole (1990), ${ }^{34}$ state ownership is only one form of the continuum of governance structures that reflect the level of state regulation. The attitude of international organizations has been modified, too. While in the 1990s they sharply criticized public ownership and encouraged privatization, nowadays they admit that there are legitimate economic and social reasons for setting up and

\footnotetext{
${ }^{34}$ Among those presenting similar approaches are Rose (1989) and Letza et al. (2004).
} 
maintaining state-owned firms; what is important, rather than selling the state enterprises, is to ensure that they operate in line with the market principles. ${ }^{35}$

The consensus is tending toward the recognition that the dichotomous approaches are simplistic: both state and private ownerships cover many types of firm and functioning. Hence, the central issue in theory and in economic policy is not the state intervention or the volume of ownership changes, but the transformation of the mode of operation. This affects the state, the firm and the whole institutional system of their relationship, including the legal framework, the quality of governance, traditions and norms. The object of examination then becomes the range of incremental changes, and the "moments of state ownership" may well disappear.

\section{REFERENCES}

Aharoni, Y. (1986): The Evolution and Management of State-Owned Enterprises. Cambridge, MA.: Ballinger.

Alchian, A. A. (1965): Some Economics of Property Rights. Il Politico, 30(4): 816-829.

Backhaus, J. G. (1989): Privation and Nationalization. Annals of Public and Cooperative Economy, 60(3): 307-329.

Bartsch, E. - Ng, E. (2010): Towards Fiscal Tightening and Privatization: Implications for Equities. In: Privatization Barometer Report 2009, pp. 19-27. www.privatizationbarometer.net Last accessed 08.08.2017.

Berend, T. I. (2006): An Economic History of Twentieth-Century Europe: Economic Regimes from LaissezFaire to Globalization. Cambridge: Cambridge University Press.

Berman, S. (2006): The Primacy of Politics: Social Democracy and the Making of Europe's Twentieth Century. Cambridge: Cambridge University Press.

Bernanke, B. S. (2015): The Courage to Act: A Memoir of a Crisis and Its Aftermath. New York: W. W. Norton \& Company.

Bortolotti, B. - Fotak, V. - Megginson, W. L. - Miracky, W. F. (2010): Sovereign Wealth Fund Investment Patterns and Performance. Nota di Lavoro 22.2009.

Bortolotti, B. - Milella, V. (2006): Privatization in Western Europe Stylized Facts, Outcomes, and Open Issues. Fondacione ENI Enrico Mattei Working Papers, No. 2006/124.

Bortolotti, B. - Pinotti, P. (2003): The Political Economy of Privatization. SSRN Electronic Journal, May https://www.researchgate.net/publication/5023181 Last accessed 10.06.2017.

Boyco, M. - Shleifer, A. - Vishny, R. (1996): A Theory of Privatization. The Economic Journal, 106(435): 309-319.

Bräuninger, D. (2013): Privatisation in the Euro Area: Differing Attitudes towards Public Assets. Research Briefing, 20. August, Deutsche Bank Research, Frankfurt/Main.

Bremmer, I. (2010): The End of the Free Market: Who Wins the War between States and Corporations? New York: Portfolio-Penguin.

Campbell, J. L. (2010): Institutional Reproduction and Change. In: Morgan, G. - Campbell, J. L. - Crouch, C. - Pedersen, O. K. - Whitley, R. (eds): The Oxford Handbook of Comparative Institutional Analysis. Oxford: Oxford University Press, pp. 87-116.

\footnotetext{
${ }^{35}$ World Bank (2006), PricewaterhouseCoopers (2015) and OECD (2016).
} 
Capoccia, G. - Kelemen, D. (2007): The Study of Critical Junctures Theory. Narrative and Counterfactuals in Historical Institutionalism. World Politics, 59(April): 341-369.

Carlsson, B. (1988): Public Industrial Enterprises in Sweden. Annals of Public and Cooperative Economy, 59(2): 175-195.

Chang, R. - Hevia, C. - Loayza, N. (2009): Privatization and Nationalization Cycles. Word Bank Policy Research Working Paper, No. 5029.

Chua, A. L. (1995): The Privatization-Nationalization Cycle: The Link between Markets and Ethnicity in Developing Countries. Columbia Law Review, 95(2): 223-303.

Davidson, N. M. - Dyal-Chand, R. (2011): Property in Crisis. Northeastern University School of Law Working Papers Series, No. 56-2011 http://ssrn.com/abstract=1557815 Last accessed 22.02.2017.

Davids, M. - van Zanden, J. L. (2000): Reluctant State and Its Enterprises. In: Toninelli, P. A. (ed.): The Rise and Fall of State-Owned Enterprise in the Western World. Cambridge: Cambridge University Press, pp. 253-272.

De Ru, H. J. (1985): Public Enterprises in the Netherlands: A Tradition in Privatization. Annals of Public and Cooperative Economy, 56(3): 313-342.

Demetriades, P.- Andrianova, S.- Shortland, A. (2010): There should be no Rush to Privatise Government Owned Banks. http://www.voxeu.org/article/don-t-rush-privatise-government-owned-banks Last accessed 29. 10. 2015.

Denisova, I. - Eller, M. - Frye, T. - Zhuravskaya, E. (2011): Everyone Hates Privatization, but Why? Survey Evidence from 28 Post-Communist Countries. http://ssrn.com/abstract=1604616, Last accessed 25. 10. 2015.

Demsetz, H. (1967): Toward a Theory of Property Rights. The American Economic Review, 57(2): 347-359.

Demsetz, H. (2002): Toward a Theory of Property Rights: The Competition between Private and Collective Ownership. Journal of Legal Studies, XXXI(June): 653-672.

Esser, J. (1989): Symbolic Privatisation: The Politics of Privatisation in West Germany. In: Vickers, J. Wright, V. (eds): The Politics of Privatisation in Western Europe. London: Frank Cass, pp. 61-73.

Farrell, H. - Quiggin, J. (2012): Consensus, Dissensus and Economic Ideas: The Rise and Fall of Keynesianism during the Economic Crisis. http://www.henryfarrell.net/Keynes.pdf.

Friedman, M. (1962): Capitalism and Freedom. Chicago: University of Chicago Press.

Furubotn, E. G. - Pejovich, S. (1972): Property Rights and Economic Theory: A Survey of Recent Literature. Journal of Economic Literature, 10(4): 1137-1162.

Galambos, L. (2000): State-Owned Enterprises in a Hostile Environment. In: Toninelli, P. A. (ed.): The Rise and Fall of State-Owned Enterprise in the Western World. Cambridge: Cambridge University Press, pp 273-302.

Glaeser, E. L. (2001): Public Ownership in the American City. NBER Working Paper, No. 8613, http://www. nber.org/papers/w8613. Last accessed 22.03.2017.

Guedhami, O. (2013): Characteristics of Government Acquisitions over Time: International Evidence and Crisis Effect. In: Privatization Barometer Report 2012, pp. 30-43. www.privatizationbarometer.net. Last accessed 11.08.2017.

Hall, D. (2012): Re-Municipalising Municipal Services in Europe. Public Services International Research Unit, http://www.epsu.org/IMG/pdf/Redraft_DH_remunicipalization.pdf. Last accessed 25.04. 2015.

Hirschman, A. (1982): Shifting Investments: Private Interest and Public Action. Oxford: Blackwell.

Jensen, M. C. - Meckling, W. H. (1976): Theory of the Firm: Managerial Behavior, Agency Costs and Ownership Structure. Journal of Financial Economics, 3(4): 305-360.

Kuhn, T. S. (1962): The Structure of Scientific Revolutions. Chicago: University of Chicago Press. 
Laffont, J-J. - Tirole, J. (1990): Privatization and Incentives. Massachusetts Institute of Technology, Department of Economics, Working Paper, No. 572.

Letza, S. R. - Smallman, C. - Sun, X. (2004): Reframing Privatisation: Deconstructing the Myth of Efficiency. Policy Sciences, 37(2): 159-183.

Lopes-de-Silanes, F. - Shleifer, A. - Vishny, R. (1995): Privatization in the United States. NBER Working Paper, No. 5113.

Mazzucato, M. (2011): The Entrepreneurial State. London: Demos.

Megginson, W. L. (2010): Privatization Trends and Major Deals in 2009. The Privatization Barometer Report 2009, 7-18. www.privatizationbarometer.net.

Megginson, W. L. (2013): Privatization Trends and Major Deals in 2012 and in 2013. In: The Privatization Barometer Report 2012, pp. 3-24. www.privatizationbarometer.net Last accessed 10.08.2017.

Megginson, W. L. (2014): Privatization Trends and Major Deals in 2013 and 2014. In: The Privatization Barometer Report 2013/2014, pp. 4-25. www.privatizationbarometer.net. Last accessed 27. 02. 2015.

Megginson, W. L. (2017): Privatization, State Capitalism, and State-Ownership of Business in the 21st Century. Foundations and Trends in Finance, 11(1-2): 1-153.

Megginson, W. L. - Netter, J. M. (2003): History and Methods of Privatization. In: Parker, D. - Saal, D. (eds): International Handbook of Privatisation. Cheltenham: Edward Elgar, pp. 25-40.

Mihályi, P. (2010): A magyar privatizáció krónikája (The Encyclopedia of Hungarian Privatization). University of Pannonia, Veszprém and Centre for Economic and Regional Studies, Institute of Economics, Budapest.

Millward, R. (2011): Public Enterprise in the Modern Western World: A Historical Analysis. Annals of Public and Cooperative Economics, 82(4): 375-398. http://dx.doi.org/10.1111/j.1467-8292.2011.00447.

Mises, L. von (1922/1951): Socialism. An Economic and Sociological Analysis. New Haven: Yale University Press.

Morgan, G. - Campbell, J. L. - Crouch, C. - Pedersen, O. K. - Whitley, R. (2010): The Oxford Handbook of Comparative Institutional Analysis. Oxford: Oxford University Press.

Musacchio, A. - Lazzarini, S. G. (2012): Leviathan in Business: Varieties of State Capitalism and their Implications for Economic Performance. Harvard Business School Working Paper, No. 12-108.

North, D. (1990): Institutions. Institutional Change and Economic Performance. Cambridge, New York: Cambridge University Press.

OECD (2016): State-Owned Enterprises as Global Competitors. A Challenge or an Opportunity? Paris.

Parker, D. (2003): Privatization in the European Union. In: Parker, D. - Saal, D. (eds): International Handbook of Privatisation. Cheltenham: Edward Elgar, pp. 105-128.

Parker, D. (2013): Privatization and the Labour Governments 1997-2010. Annals of Public and Cooperative Economics, 84(4): 343-360.

Parris, H. (1985): Public Enterprises in Great Britain. Annals of Public and Cooperative Economics, 56(3): 393-410.

Pigeon, M. - McDonald, D. A.- Hoedeman, O. - Kishimoto, S. (eds) (2012): Putting Water Back into Public Hands. Transnational Institute, Amsterdam. www.tni.org/sites/www.tni.org/files/download/ remunicipalisation_book_final_for_web.pdf. Last accessed 19. 06.2016.

Polanyi, K. (1946/2001): The Great Transformation. The Political and Economic Origins of Our Time. Boston: Beacon Press.

PricewaterhouseCoopers (2015): State-Owned Enterprises: Catalysts for Public Value Creation? https:// www.pwc.com/gx/en/psrc/publications/assets/pwc-state-owned-enterprise-psrc.pdf. Last accessed 15.10.2018. 
Przeworski, A. (1997): The State in a Market Economy. In: Nelson, J. M. - Tilly, Ch. - Walker, L. (eds): Transforming Post-communist Political Economies. Washington D.C.: National Academy Press, pp. 411-420.

Rosa, J-J. (1993): Nationalization, Privatization, and the Allocation of Financial Property Rights. Public Choice, 75: 317-337.

Rosa, J-J. - Pérard, E. (2008): When to Privatize? When to Nationalize? A Competition for Ownership Approach. Paris: SciencePo.

Rose, R. (1989): Privatization as a Problem of Satisficing and Dissatisfying. American Review of Public Administration, 19(2): 97-118.

Shirley, M. (1992): The What, Why, and How of Privatization: A World Bank Perspective. Fordham Law Review, 60(6): 23-36.

Shleifer, A. (1998): State versus Private Ownership. NBER Working Paper series, No. 6665.

Shleifer, A. - Vishny, R. (1994): Politicians and Firms. The Quarterly Journal of Economics, 109(4): 9951025.

Somai, M. (2016): Az állam szerepe a francia gazdaságban (The Role of the State in the French Economy). Centre for Economic and Regional Studies, Institute of Economics, Working Papers, No. 112/2016.

Stigler, G. J. (1971): The Theory of Economic Regulation. Bell Journal of Economics and Management Science, 2(1): 3-21.

Stiglitz, J. (2001): The Rebel Within. Anthem World Economics. London: Wimbledon Publishing Co.

Streek, W. (2010): Institutions in History: Bringing Capitalism Back in. In: Morgan, G. - Campbell, J. L. Crouch, C. - Pedersen, O. K. - Whitley, R. (eds): The Oxford Handbook of Comparative Institutional Analysis. Oxford: Oxford University Press, pp. 659-686.

Toninelli, P. A. (ed.) (2000): The Rise and Fall of State-Owned Enterprise in the Western World. Cambridge: Cambridge University Press.

Toninelli, P. A. (2008): From Private to Public to Private Again: A Long-Term Perspective on Nationalization. Análise Social, 43(4): 675-692.

Vickers, J. - Wright, V. (1989): The Politics of Privatisation in Western Europe. London: Frank Cass.

Visvizi, A. (2012): The Crisis in Greece and the EU-IMF Rescue Package: Determinants and Pitfalls. Acta Oeconomica, 62(1): 15-39.

Voszka, É. (2017): Nationalization or Privatization? The Fragmentation of the Mainstream. Annals of Public and Cooperative Economics, 88(1): 91-120.

Voszka, É. (2018): Az állami tulajdon pillanatai, gazdaságtörténeti és tudománytörténeti nézőpontok (Moments of State Ownership. Economic Historical and Theoretical Aspects). Budapest: Akadémia Kiadó.

Walters, K. D. - Monsen, R. J. (1981): The Spreading Nationalization of European Industry. Columbia Journal of World Business, 16(4): 62-73.

Wengenroth, U. (2000): The Rise and Fall of State-Owned Enterprise in Germany. In: Toninelli, P. A. (ed.): The Rise and Fall of State-Owned Enterprise in the Western World. Cambridge: Cambridge University Press, pp. 103-127.

Williamson, O. E. (1996): The Mechanisms of Governance. Oxford: Oxford University Press.

Willner, J. (2003): Privatization: A Sceptical Analysis. In: Parker, D. - Saal, D. (eds): International Handbook of Privatisation. Cheltenham: Edward Elgar, pp. 60-86.

World Bank (2006): World Development Report 2006. Equity and Development. https://openknowledge. worldbank.org/bitstream/handle/10986/5988/WDR\%202006\%20-\%20English.pdf?sequence=3\&is Allowed $=\mathrm{y}$ Last accessed 11.02.2019. 
Yarrow, G. (1986): Privatization in Theory and Practice. Economic Policy, 1: 323-377.

Yarrow, G. - Jasinski, P. (eds) (1996): Privatization - Critical Perspectives and the World Economy. London, New York: Routledge.

Yergin, D. - Stanislaw, J. (2002): The Commanding Heights: The Battle for the World Economy. New York: Touchston.

Open Access. This is an open-access article distributed under the terms of the Creative Commons Attribution 4.0 International License (https://creativecommons.org/licenses/by/4.0/), which permits unrestricted use, distribution, and reproduction in any medium, provided the original author and source are credited, a link to the CC License is provided, and changes - if any - are indicated. (SID_1) 